\title{
The effect of number of daily meals for dairy cows on milk yield and composition
}

\author{
Z. Shabi ${ }^{1 *}$, I. Bruckental ${ }^{2}$, H. Tagari', S. Zamwel ${ }^{1}$, G. Adin ${ }^{3}$ \\ and A. Arieli ${ }^{\prime}$ \\ 'Ilebrew University, Faculty of Agriculture \\ Rehovot 76100, Israel \\ 'Institute of Animal Science, Agriculture Research Organization, \\ The Volcani Center \\ Bet Dagan 50250, Israel \\ ${ }^{3}$ Ministry of Agriculture, Extension Service \\ Rehovot 76324, Israel
}

(Received 11 September I997; accepted 24 June 1998)

\begin{abstract}
The effect of the number of daily meals on milk yield and composition was studicd in a commercial dairy herd. One hundred and eighty Israeli Holstein cows were divided into two groups. One group was given onc meal daily and the second group three meals daily. Feeding frequency had no effect on DM intake, milk yield or milk composition. Total VFA and molar proportion of acetate were higher before feeding than $3 \mathrm{~h}$ later. The decrease in molar proportion of acetate after feeding was greater in the cows given one meal daily. The propionate molar proportion was higher before feeding and lower $3 \mathrm{~h}$ later if cows were given three meals daily. As a result, the acetate to propionatc ratio was lower in cows fed three meals daily before feeding and rose after $3 \mathbf{h}$. Ruminal ammonia- $\mathrm{N}$ concentrations, before and after feeding, were lower when cows were fed three meals daily. Plasma urea- $\mathrm{N}$ concentrations were higher before feeding, as comparcd with $3 \mathrm{~h}$ later. Plasma ured-N was higher for the one meal treatment, but significantly only $3 \mathrm{~h}$ after the morning meal. It is suggested that increasing fecding frequency may improve dietary nitrogen utilization and may shift metabolism towards more gluconcogencsis. Production responses to more frequent feeding are more likely to be revealed in high yielding dairy cows, maintained on high concentrate diets.
\end{abstract}

KEY WORDS: feeding frequency, rumen, dairy cows

* Corresponding author 


\section{INTRODUCTION}

Increasing the amount of concentrate in the diet ( $50 \%$ and more of dietary DM) is now a common feeding strategy as a means of increasing the energy and protein density of diets fed to high producing dairy cows. Diets fed in excess of protein requirement may result in high concentrations of urca in blood, milk and urine (Roseler et al., 1993) and might be associated with impaired fertility (Ferguson et al., 1989) and increased environmental pollution (NRC, 1985; Tamminga, 1992). Feeding frequency affects ruminal and blood metabolites (Sutton et al., 1986, 1988); a higher feeding frequency may counteract these effects, enhance diet utilization (Robinson and McNiven, 1994) and decrease ruminal ammonia $\mathrm{N}\left(\mathrm{NH}_{3}-\mathrm{N}\right)$ and plasma urea-N (PUN) concentrations. In our previous study (Shabi ct al., 1998), diets were fed to cows equipped with rumen and abomasum cannulas, four versus two daily meals. In that study, the concentrations of PUN, 2 and $4 \mathrm{~h}$ after feeding, were lower when cows were fed four meals than when cows were fed two meals daily. The present study investigates, under commercial conditions, the effect of feeding frequency of total mix ration on performance of high producing dairy cows consuming a high-concentrate diet.

\section{MATERI $\Lambda L$ AND METHODS}

\section{Cow and treatments}

The experiment was carried out on the herd of the Mevo-Choron kibbutz, on 180 Israeli-Holstein cows (54 primiparous cows, $120 \pm 30 \mathrm{DIM}$ ) that were divided into two treatments, as follows: 1 . Control. The daily ration was given once a day, at $07.00 \mathrm{~h}, 2$. Experimental. The daily ration was given in three meals, at $07.00 \mathrm{~h}$ ( $50 \%$ of daily amount), $13.00 \mathrm{~h}$ ( $30 \%$ of daily amount) and $22.00 \mathrm{~h}(20 \%$ of daily amount). Cows werc assigned to the dietary treatments according to lactation date, parity number, and milk yield during previous lactation. The duration of the experiment was three months.

The dict contained a common blend of ingredients (Table 1). calculated using a lcast-cost linear program (Gavish, (jiv'at Brener, Israel). The diet was formulated to contain (on DM basis) forage 36\%, NEL 1.75 Mcal, CP $16.9 \%$, rumen degradable CP (RDCP, \% of CP) $69.7 \%$, rumen degradable OM (RDOM, \% of OM) $56.1 \%$, NDF $31.5 \%$ and NSC $38 \%$. The hourly ratio between RDOM and RDCP, calculated from the in situ data, is presented in Figure 1 . The cows were group-fed and the ration was offered as a totally mixed ration (TMR) for ad libitum intake, and was moved close to the cows a few times daily. The daily consumption of each treatment group was recorded. Refusals from each treatment, which were usually $5 \%$ 
TABLE 1

Composition of experimental diet

\begin{tabular}{|c|c|c|c|}
\hline Ingredients & & $\%$ in DM & \\
\hline Ground maize & 8.0 & Chemical composition & \\
\hline Cracked maize & 3.1 & crude protein & 16.9 \\
\hline Barley & 9.1 & $\mathrm{NDF}$ & 31.5 \\
\hline Sorghum & 2.3 & $\mathrm{NSC}$ & 38.0 \\
\hline Gluten feed & 5.9 & $\mathrm{RDCP}^{3}$ & 69.7 \\
\hline Whole cotton seed & 13.9 & $\mathrm{RDPM}^{4}$ & 56.1 \\
\hline Soyabean meal & 3.6 & NEL, Mcal & 1.75 \\
\hline Rapesced meal & 3.2 & & \\
\hline Sunflower meal & 2.3 & & \\
\hline Fish meal & 0.7 & & \\
\hline Wheat silage & 7.2 & & \\
\hline Maize silage & 19.8 & & \\
\hline Pea hay & 5.7 & & \\
\hline Citrus peels & 6.2 & & \\
\hline Molasses & 6.7 & & \\
\hline Urea & 0.3 & & \\
\hline Ammonium sulfate & 0.1 & & \\
\hline FA-Ca-salt & 0.07 & & \\
\hline Oil & 0.2 & & \\
\hline Vitamins and mineral $^{2}$ & 1.7 & & \\
\hline
\end{tabular}

${ }^{i}$ treated with $\mathrm{NaOII}$

2 contained (per $20 \mathrm{~kg}$ TMR) $16 \times 106$ IU of vitamin A, $3.2 \times 106$ IU of vitamin D, 16 x 106 IU of vitamin E, $196 \mathrm{~g} \mathrm{CaCO}, 91 \mathrm{~g} \mathrm{NaCl}, 48 \mathrm{~g}$ of Mo, $48 \mathrm{~g}$ of $\mathrm{Zn}, 48 \mathrm{~g}$ of Fe, $19.2 \mathrm{~g}$ of Cu, $3.4 \mathrm{~g}$ of I, $0.32 \mathrm{~g}$ of $\mathrm{Co}$, and $0.48 \mathrm{~g}$ of $\mathrm{Se}$

RDCP - rumen degradable $\mathrm{CP}$

${ }^{4} \mathrm{RDOM}=$ rumen degradable $\mathrm{OM}$

of offered diet, were also recorded every morning. Diets were sampled once a week, and refusals were sampled daily, for DM, CP and NDF analyses.

Rumen fluid and blood from 40 cows of each treatment group were sampled during the third month, before the morning meal was offered and $3 \mathrm{~h}$ later. Ruminal fluid samples were taken by ruminal tube. Blood samples for determination of PUN were taken from the coccygeal vessels before feeding and $3 \mathrm{~h}$ after feeding.

\section{Milk yield and composition}

Cows were milked at $05.00,13.00$ and $21.00 \mathrm{~h}$. Milk yield was recorded for each milking by the Afimilk System (Afikim, Isracl). Milk samples from three consecutive milking events were collected every 14 days and analyzed for fat, protein and lactose by an infrared procedure at the Israel Cattle Association Laboratories. 


\section{Chemical analyses}

Chemical analyses of feeds were performed on dry, 2-mm milled feed samples. Dry matter was assayed after the sample was dried at $105^{\circ} \mathrm{C}$ for $12 \mathrm{~h}$, except for silage and citrus peels, which were first dried at $60^{\circ} \mathrm{C}$ for $48 \mathrm{~h}$. The OM content was determined following ashing at $600^{\circ} \mathrm{C}$ for $3.5 \mathrm{~h}$. The $\mathrm{CP}$ content was analyzed by the Kjeldahl auto analyzer (Tecator, Höganäs, Sweden). The NDF was determined according to the method of Van Soest et al. (1991). Ruminal degradabilities of $\mathrm{OM}$ and $\mathrm{CP}$ in dictary feeds were determined by the dacron-bag technique in situ (Ørskov and McDonald, 1979) and as described by Arieli et al. (1989).

Samples of rumen fluid were divided into subsamples for determination of VFA ( $10 \mathrm{ml}$ mixed with $750 \mu \mathrm{l}$ saturated $\mathrm{HgCl}_{2}$ ) and $\mathrm{NH}_{3}-\mathrm{N}(5 \mathrm{ml}$ mixed with $5 \mathrm{ml} 20 \%$ trichloroacetic acid), and were kept frozen $\left(-20^{\circ} \mathrm{C}\right)$ until analyzed. Ruminal fluid $\left(0.4 \mathrm{ml}+0.1 \mathrm{ml} 25 \% \mathrm{HPO}_{3}\right.$, and $0.1 \mathrm{ml}$ isocaproic acid) was centrifuged at $3000 \mathrm{x} \mathrm{g}$ for $15 \mathrm{~min}$ and VFA were assessed by GLC (Model 5890, Hewlett Packard, Avondale, PA) on $0.3 \%$ Carbovax $20 \mathrm{M}$ with $0.1 \%$ phosphoric acid (Supelco, Bellefonte, $\mathrm{PA})$. Ammonia- $\mathrm{N}$ concentration in ruminal fluid on centrifuged sample $(3000 \mathrm{xg}$ for $15 \mathrm{~min}$ ) was determined by the phenol procedure of Krom (1980).

Plasma urea content was analyzed according to the method described by Tagari (1969).

\section{Statistical analyses}

Data were analyzed by ANOVA using the GLM procedure of SAS (1985) to examine the effect of cow, number of lactations, feeding frequency, and their interactions on metabolites, milk yield and milk composition. Treatment means were compared by a contrast $t$ test, following significance for the ANOVA model.

\section{RESULTS $\Lambda$ ND DISCUSSION}

According to data given in Table 2, feeding frequency had no significant effect on DM intake. This finding conforms with other studies in which feeding frequency did not affect DM intake (Yang and Varga, 1989; Klusmeyer et al., 1990). Milk yield and percentage and yield of milk-protein, fat and lactose were higher for multiparous than for primiparous cows, but no effect of feeding frequency could be identified. The lack in milk response to frequency of fecdings in our study is in agreement with results published by others (Nocek and Braund, 1985; French and Kennelly, 1990; Klusmeyer et al., 1990). Robinson and McNiven (1994), however, observed an increase in DM intake and milk yield when cows were fed seven vs 
TABLE 2

Effect of fceding frequency on DM intake, milk yield and composition of primiparous $(\mathrm{P})$ and multiparous (M) cows

\begin{tabular}{|c|c|c|c|c|c|c|c|c|}
\hline \multirow{2}{*}{$\begin{array}{l}\text { Feeding frequency } \\
\text { Lactation no. }\end{array}$} & \multicolumn{2}{|c|}{$\mathrm{x} 1$} & \multicolumn{2}{|c|}{$\times 3$} & \multirow[b]{2}{*}{ SEM } & \multicolumn{3}{|c|}{ Main effect } \\
\hline & $\mathbf{P}$ & $\mathrm{M}$ & $\mathrm{P}$ & M & & LAC & $\mathrm{FF}$ & PxFF \\
\hline DM intake, $\mathrm{kg} / \mathrm{d}$ & 22.4 & 22.4 & 22.5 & 22.5 & & & & \\
\hline Milk yield, kg/d & 34.0 & 37.0 & 34.3 & 37.6 & 0.33 & 0.002 & 0.820 & 0.917 \\
\hline \multicolumn{9}{|l|}{ Milk protcin } \\
\hline$\%$ & 2.93 & 3.07 & 2.96 & 3.02 & 0.01 & 0.052 & 0.815 & 0.990 \\
\hline $\mathrm{kg} / \mathrm{d}$ & 0.98 & 1.12 & 0.97 & 1.10 & 0.01 & 0.001 & 0.937 & 0.688 \\
\hline \multicolumn{9}{|l|}{ Milk fat } \\
\hline$\%$ & 3.52 & 3.73 & 3.55 & 3.66 & 0.03 & 0.007 & 0.395 & 0.146 \\
\hline $\mathrm{kg} / \mathrm{d}$ & 1.18 & 1.37 & 1.17 & 1.34 & 0.02 & 0.003 & 0.620 & 0.510 \\
\hline \multicolumn{9}{|l|}{ Milk lactose } \\
\hline$\%$ & 4.60 & 4.58 & 4.62 & 4.57 & 0.01 & 0.646 & 0.414 & 0.980 \\
\hline $\mathrm{kg} / \mathrm{d}$ & 1.54 & 1.68 & 1.52 & 1.68 & 0.01 & 0.001 & 0.664 & 0.802 \\
\hline
\end{tabular}

two meals. However, diets high in barley, which is highly fermentable in the rumen, were used in that expcriment.

The level of VFA, $\mathrm{NH}_{3}-\mathrm{N}$ in rumen fluid and PUN are presented in Table 3. Before the morning meal, the molar proportions of acetate and butyrate were higher and that of propionate was lower when cows were fed one vs three meals daily. As a result, the acetate to propionate ratio was lower before the morning meal was

TABLE 3

Effect of fecding frequency on ruminal fluid $\mathrm{pH}$ and on levels of VFA and ammonia-N and on plasma urea-N

\begin{tabular}{|c|c|c|c|c|c|c|c|c|}
\hline \multirow{2}{*}{$\begin{array}{l}\text { Time of sampling } \\
\text { Feeding frequency }\end{array}$} & \multicolumn{2}{|c|}{ Before meal } & \multicolumn{2}{|c|}{$3 \mathrm{~h}$ after meal } & \multirow[b]{2}{*}{ SEM } & \multicolumn{3}{|c|}{ Main effect } \\
\hline & $x 1$ & x 3 & $\times 1$ & $\times 3$ & & time & $\mathrm{FF} \mathrm{t}$ & time $x \mathrm{FF}$ \\
\hline $\begin{array}{c}\text { VFA, } \% \text { of total: } \\
\text { acetate }(\Lambda)\end{array}$ & $65.2^{\mathrm{a}}$ & $63.0^{6}$ & $60.9^{c}$ & $61.0^{\mathrm{bc}}$ & 0.40 & 0.004 & 0.221 & 0.167 \\
\hline propionate $(\mathrm{P})$ & $21.3^{\mathrm{c}}$ & $24.2^{\mathrm{a}}$ & $22.6^{\mathrm{b}}$ & $21.0^{c}$ & 0.24 & 0.036 & 0.155 & 0.001 \\
\hline butyrate & $10.4^{\mathrm{t}}$ & $9.9^{\circ}$ & $13.3^{\mathrm{a}}$ & $12.5^{\mathrm{b}}$ & 0.11 & 0.001 & 0.015 & 0.336 \\
\hline isovalerate & $1.18^{\mathrm{a}}$ & $0.99^{\mathrm{b}}$ & $1.16^{\mathrm{a}}$ & $1.06^{\circ}$ & 0.01 & 0.556 & 0.001 & 0.070 \\
\hline valerate & $1.49^{\mathrm{a}}$ & $1.46^{\mathrm{a}}$ & $1.55^{\mathrm{a}}$ & $1.37^{\mathrm{b}}$ & 0.02 & 0.589 & 0.017 & 0.056 \\
\hline $\mathrm{A}: \mathrm{P}$ & $3.11^{\mathrm{a}}$ & $2.69^{\circ}$ & $2.69^{\mathrm{h}}$ & $2.92^{\mathrm{a}}$ & 0.04 & 0.353 & 0.186 & 60.0001 \\
\hline Total VFA, mM & $98.9^{\mathrm{a}}$ & $99.7^{a}$ & $84.3^{\mathrm{b}}$ & $81.3^{\mathrm{b}}$ & 1.30 & 0.001 & 0.619 & $9 \quad 0.536$ \\
\hline Ammonia-N, mg/dl & $14.9^{\mathrm{b}}$ & $10.8^{\mathrm{c}}$ & $16.8^{\mathrm{a}}$ & $10.8^{\mathrm{c}}$ & 0.30 & 0.049 & 0.001 & 0.122 \\
\hline Urea $\mathrm{N}, \mathrm{mg} / \mathrm{dl}$ & $16.8^{\mathrm{a}}$ & $16.1^{\mathrm{a}}$ & $15.2^{\mathrm{b}}$ & $14.1^{\mathrm{c}}$ & 0.11 & 0.001 & 0.001 & 0.115 \\
\hline
\end{tabular}

$\mathrm{a}, \mathrm{b}, \mathrm{c}-$ means within rows with different superscripts diffcr, $\mathrm{P}<0.05$ 
offered when cows were fed three meals. $\Lambda$ trend towards a higher propionate and lower acetate to propionate ratio was observed when cows were fed four vs two mcals daily (Klusmeyer et al., 1990). However, in other studies, no effect of more frequent meals on VFA molar proportion was observed (Sutton et al., 1986; Yang and Varga, 1989). Three $h$ after fecding, the molar proportion of VFA was higher when cows were fed one meal than when cows reccived three daily meals, suggesting greater consumption in the morning meal when cows were fed once daily. While cows in our expcriment were fed with different frequencies, feed remained available to them between feedings. Nevertheless, fermentation was affected by fecding frequency, suggesting that cows consumed the main part of the dict according to the feeding strategy.

Ammonia- $\mathrm{N}$ concentrations in ruminal fluid, before and $3 \mathrm{~h}$ after the ration was offered, were lower when cows were fed three meals as comparcd with one meal (Table 3). Lower $\mathrm{NH}_{3}-\mathrm{N}$ concentration 2 and $4 \mathrm{~h}$ after feeding when cows were fed more frequent meals was in line with data shown by Yang and Varga (1989). Plasma urea- $\mathrm{N}$ concentrations were higher before the morning meal was offered, as compared with 3 h later. The PUN concentration was higher when cows were fed one meal, but it was significantly higher only $3 \mathrm{~h}$ after the morning meal was offered. Plasma urea-N concentrations can be indicative of ammonia loss from the rumen and represent the efficiency of processes related to protein metabolism. Therefore, lower PUN concentrations might indicate a higher efficiency of $\mathrm{N}$ utilization in the cow. Furthermore, a decrease of PUN concentrations might reduce milk non-protein N (Roseler et al., 1993).

The relation between ruminal VFA and ruminal $\mathrm{NH}_{3}-\mathrm{N}$ concentration is presented in Table 4. A high proportion of ruminal acetate before the morning meal correlated with a reduced $\mathrm{NII}_{3}-\mathrm{N}$ concentration: $\mathrm{NH}_{3}-\mathrm{N}(\mathrm{mg} / \mathrm{dl})=34.74( \pm 10.4)$ $-0.34( \pm 0.16) \times$ acetate (molar proportion), $\mathrm{n}-58, \mathrm{R}=0.27, \mathrm{P}<0.05$. The linkage between ruminal acetate and ammonia may be due to incorporation of ammonia by fibre-digesting microbes (Nocek and Russell, 1988). When cows were fed one daily meal, increases in ruminal butyrate and ammonia concentrations were obscrved. The increase in the proportion of ruminal butyrate was found to be affected by the presence of ruminal protozoa (Grummer et al., 1983; Whitelaw et al., 1984). The presence of protozoa in the rumen might explain the increased concentration of ruminal ammonia, suggesting a lower number of ruminal protozoa when cows werc fed three vs one meal daily. Three h after the morning meal, increased molar proportion of ruminal butyrate and ruminal ammonia concentrations were found in both feeding frequencies. It seems that the number and/or activity of ruminal protozoa were increased, and recycling of bacteria was increased after feeding. These data concur with those published by Martin et al. (1994) in which the number of Holotrichs was found to be higher two hours after fecding than five or $23 \mathrm{~h}$ later. When cows were fed three meals, an increase in propionate molar 
Effect of feeding frequency on the relation between ruminal VFA and ammonia- $\mathrm{N}$

\begin{tabular}{ll}
\hline Feeding frequency & \multicolumn{1}{c}{ Before meal: } \\
\hline $\mathrm{xl}$ & Ammonia $\mathrm{N}(\mathrm{mg} / \mathrm{dl})=$ acetate $(\%) \times-0.83(+0.3)+68.94( \pm 19.9)$ \\
& $\mathrm{R}=0.46, \mathrm{P}<0.05, \mathrm{n}=30$ \\
& Ammonia $\mathrm{N}(\mathrm{mg} / \mathrm{d} \mathrm{l})=$ butyratc $(\%) \times 2.18( \pm 0.6)-8.18( \pm 6.0)$ \\
& $\mathrm{R}=0.58, \mathrm{P}<0.01, \mathrm{n}=30$ \\
& Ammonia $\mathrm{N}(\mathrm{mg} / \mathrm{dl})=$ total $\mathrm{VFA}(\mathrm{mM}) \times 0.16( \pm 0.1)-1.46( \pm 7.4)$ \\
& $\mathrm{R}=0.38, \mathrm{P}<0.05, \mathrm{n} 30$ \\
& Ammonia $\mathrm{N}(\mathrm{mg} / \mathrm{dl})=$ acetate $(\%) \times-0.56( \pm 0.1)+45.81( \pm 8.2)$ \\
& $\mathrm{R}=0.64, \mathrm{P}<0.01, \mathrm{n}=28$ \\
& Ammonia $\mathrm{N}(\mathrm{mg} / \mathrm{dl})-$ propionate $(\%) \times 0.51( \pm 0.1)-1.57( \pm 3.5)$ \\
& $\mathrm{R}=0.57, \mathrm{P}<0.01, \mathrm{n}=28$ \\
& Ammonia $\mathrm{N}(\mathrm{mg} / \mathrm{dl})=$ total VFA $(\mathrm{mM}) \times 0.15( \pm 0.1)-4.01( \pm 3.7)$ \\
& $\mathrm{R}=0.62, \mathrm{P}<0.01, \mathrm{n}=28$ \\
& $3 \mathrm{~h}$ after $\mathrm{meal}:$ \\
& Ammonia $\mathrm{N}(\mathrm{mg} / \mathrm{dl})-$ butyrate $(\%) \times 1.23( \pm 0.4)+0.75( \pm 5.6)$ \\
& $\mathrm{R}=0.45, \mathrm{P}<0.01, \mathrm{n}=36$ \\
& Ammonia $\mathrm{N}(\mathrm{mg} / \mathrm{dl})=$ butyrate $(\%) \times 0.71( \pm 0.3)+1.88( \pm 3.6)$ \\
& $\mathrm{R} \cdot 0.40, \mathrm{P}<0.05, \mathrm{n}=34$
\end{tabular}

proportion and a decrease in ruminal ammonia concentration were noted before feeding. The negative correlation between ruminal propionate and ammonia concentration might be caused by a decrease in ruminal acetate and butyrate in that feeding frequency. A reduced acctate to propionate ratio in ruminal fluid as a result of increasing feeding frequency were shown in our previous work (Shabi et al., 1997). In that work, increased feeding frequency was associated with a higher proportion of by-pass non-structural carbohydrates and protein in the abomasal digesta. It seems that increasing the feeding frequency may improve dietary nitrogen utilization and carbohydrate metabolism, with a shift toward more gluconeogenesis. Improvement of fecd utilization may sometimes be a result of a reduction in DM intake without affecting milk yield. In the current experiment, the cows were group-fed, and the experimental group included primiparous and multiparous cows that were not in the same stage of lactation. Accordingly, the average DMI of cach group (Table 2) might not reflect the actual experimental effect on DMI of the individual cow. Production response to more frequent feeding is more likely to be expressed in cows undergoing large perturbations in metabolite supply. Such a situation may occur in high-yielding dairy cows, maintained on high concentrate diets. 
Summary of results of studies on the effect of feeding frequency (FF) on dry matter intake, milk yield and rumen metabolites

\begin{tabular}{|c|c|c|c|c|c|c|c|c|c|c|c|}
\hline \multirow{4}{*}{ Nocck and Braund (1985) } & \multirow{4}{*}{$\begin{array}{r}\mathrm{n} \\
4 \\
30\end{array}$} & \multirow{4}{*}{$\begin{array}{l}\text { Milk } \\
\mathrm{kg} / \mathrm{d}\end{array}$} & \multirow{4}{*}{$\begin{array}{c}\text { Grains in diet, } \\
\mathrm{g} / \mathrm{kg} \\
600\end{array}$} & \multirow{4}{*}{$\begin{array}{l}\text { FF } \\
1,2,4,8 \\
1 \text { vs } 4\end{array}$} & \multirow{4}{*}{$\frac{\text { FF of: }}{\text { TMR }}$} & \multicolumn{6}{|c|}{ Effects of feeding frequency on: } \\
\hline & & & & & & \multirow{2}{*}{$\frac{\text { DMI }}{\text { NS }}$} & \multirow{2}{*}{$\frac{\text { milk }}{\mathrm{NS}}$} & \multicolumn{2}{|c|}{ milk-fat milk-protein } & \multirow[t]{3}{*}{$\mathrm{NH}_{3}-\mathrm{N}$} & \multirow[t]{3}{*}{ VFA } \\
\hline & & & & & & & & NS & NS & & \\
\hline & & & & & & NS & NS & NS & NS & & \\
\hline Robinson and Sniffen (1985) & 3 & 26 & 260 & 1 vs 4 & TMR & NS & NS & $\mathrm{NS}$ & NS & & \\
\hline Sutton et al. (1988) & 16 & 21 & $700 / 900$ & 2 vs 6 & $\mathrm{C}$ & & $\mathrm{NS}$ & $\|$ & & & \\
\hline Yang and Varga (1989) & 3 & 21 & 450 & $1,2,4$ & $\mathrm{C}$ & NS & $\mathrm{NS}$ & * & * & & \\
\hline \multirow[t]{2}{*}{ French and Kennelly (1990) } & 4 & 30 & 600 & 2 vs 12 & $\mathrm{C}$ & & $\mathrm{NS}$ & \# & NS & & \\
\hline & 6 & 37 & & 2 vs 12 & C, TMR & & Nis & NS & NS & & \\
\hline \multirow[t]{2}{*}{ Klusmeyer et al. (1990) } & 20 & 30 & 450 & 2 vs 4 & TMR & NS & NS & NS & NS & & \\
\hline & 4 & & 450 & & & & & & & NS & $\dot{Y}$ \\
\hline \multirow[t]{2}{*}{ Macleod et al. (1994) } & 20 & 28 & 650 & 2 vs 3 & $\mathrm{C}$ & NS & NS & NS & NS & NS & NS \\
\hline & 32 & 29 & 600 & $2 \mathrm{vs} 6$ & & NS & NS & NS & NS & & \\
\hline Robinson and McNiven (1994) & 24 & 36 & 490 & 2 vs 7 & Barely & $\S$ & $\$$ & & & & \\
\hline Robinson and McQueen (1994) & 24 & 36 & 550 & 2 vs 5 & Protein & NS & NS & NS & NS & NS & $a$ \\
\hline Shabi et al. (1997) & 4 & 26 & 470 & 2 vs 4 & TMR & $\dagger$ & NS & $\dagger$ & $\dagger$ & NS & $\dagger$ \\
\hline Current experiment & 180 & 36 & 650 & 1 vs 3 & TMR & NS & NS & NS & NS & \pm & $\ddagger$ \\
\hline
\end{tabular}

$\mathrm{TMR}=$ total mix ration, $\mathrm{C}=$ concentrate. $\mathrm{NS}=$ not significantly affected by feeding frequency $\mathrm{P}>0.1$

I milk-fat increased when cows were fed concentrate six vs two times daily

* milk-fat and -protein yield increased when cows were fed concentrate more than once daily. Mean daily concentration of ammonia was NS

\# milk-fat increased when cows were fed concentrate 12 vs two times daily

$Y$ Y total VFA was increased when cows were fed more frequent meals

$\S$ cows fed raw barley seven vs two times daily, increased DM intake and milk yield

$a$ total VFA and proportion of propionate decreased when cows were fed more frequent supplemental protein

$\dagger$ milk-fat and -protein percentage and yield increased, proportion of propionate increased and proportion of acetate decreased when cows fed 4 vs

2 meals

$\$$ before feeding, proportion of propionate increased, acetate decreased, ammonia concentration decreased when cows fed four vs two. After feeding ammonia concentration decreased and plasma urea concentration decreased when cows were fed four vs two meals 
Gibson (1984) summarized the effect of the frequency of feeding on milk production of cattle. In his review, significant responses of milk production to increased frequency of feeding occurred in comparisons of one or two with three or more meals per day. However, that review dealt with low-production cows. Data shown in Table 5 review published results of effect of feeding frequency on milk production and rumen fermentation from 1984 until recently. Milk yield, milk composition, and ruminal ammonia were not affected by variable experimental feeding strategy in most cases. Increasing the feeding frequency improved fibre digestion and increased milk-fat (Sutton et al., 1988; Yang and Varga, 1989; French and Kennely, 1990; Shabi et al., 1998). Milk-fat increased when concentrates were fed more frequently. Ruminal fermentation was also affected by increased feeding frequency in half of the reported cases. The greatest response to an increased number of meals in milk yield, milk composition, and metabolites was observed in cows when they were fed time-limited meals (Shabi et al.,1997).

Increasing the feeding frequency maintained a higher ratio of RDOM/RDCP from $16.00 \mathrm{~h}$ until the morning feeding (Figure 1). Higher RDOM/RDCP ratios during those hours improved $\mathrm{N}$ utilization but did not enhance milk synthesis. The diet in the present experiment contained a variety of feedstuffs. Such a variety could maintain the supply RDOM and RDCP during the day. It seems that a difference of 0.2 units of the RDOM/RDCP ratio, obtained by more frequent feeding, had small impact of diet utilization for milk synthesis. This suggests that the $\mathrm{RDOM} / \mathrm{RDCP}$ ratio can be used to predict the benefit from an increase of feeding frequency.

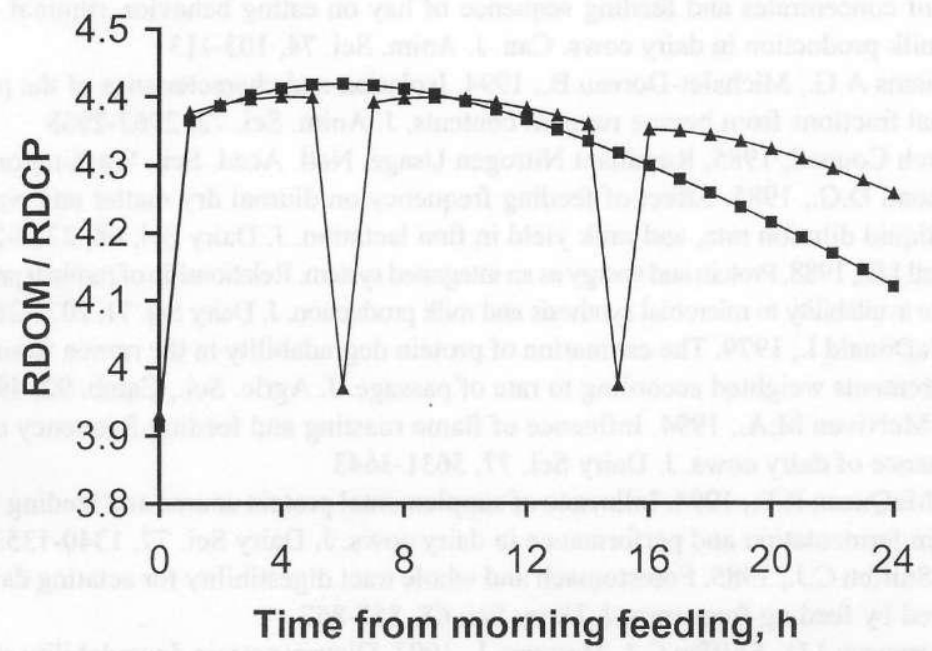

Figure 1. Hourly ratio between ruminally degradable OM (RDOM) and ruminally degradable CP (RDCP) when cows were fed once (四) or three times daily (A) 


\section{CONCIUUSIONS}

Increased feeding frequency may change the ruminal fermentation to more gluconeogenic one, and this may improve utilization of carbohydrates in the diet. More frequent meals might be a useful tool to reduce ruminal ammonia and plasma urea concentration and may reduce excretion of $\mathrm{N}$ to the environment when high-protein diets are fed to dairy cows.

\section{REFERENCES}

Arieli A., Bruckental I., Smoler E., 1989. Prediction of duodenal nitrogen supply from degradation of organic and nitrogenous matter in-situ. J. Dairy Sci. 72, 2532-2539

Ferguson J.D., Chalupa W., 1989. Impact of protein nutrition on reproduction in dairy cows. J. Dairy Sci. $72,746-766$

French N., Kennelly J.J., 1990. Effect of feeding frequency on ruminal parameters, plasma insulin, milk yicld, and milk composition in Holstcin cows. J. Dairy Sci. 73, 1857-1863

Gibson J.P., 1984. The effects of frequency of feeding on milk production of dairy cattle: $\Lambda \mathrm{n}$ analysis of published results. Anim. Prod. 38, 181-189

Girummer R.R., Staples C.R., Davis C.I., 1983. F.fiect of defaunation on ruminal volatile fatty acids and $\mathrm{pH}$ of steers fed a diet high in dried whole whey. J. Dairy Sci. 66, 1738-1741

Klusmeyer 'T.H., Cameron M.R., McCoy G.C., Clark J.H., 1990. E.ffects of feed processing and frequency of feeding on ruminal fermentation, milk production, and milk composition. J. Dairy Sci. 73, 3538-3543

Krom M.D., 1980. Spectrophotometric detcrmination of ammonia: A study of a modified Berthelot reaction using salicylate and dichloroisocyanurate. Analyst 105, 305-316

Macleod G.K., Colucci P.E., Moore A.D., Grieve D.G., Lewis N., 1994. The effects of feeding frequency of concentrates and feeding sequence of hay on eating behavior, ruminal environment and milk production in dairy cows. Can. J. Anim. Sci. 74, 103-113

Martin C., Williams A.G., Michalet-Doreau B., 1994. Isolation and characteristics of the protozoal and bacterial fractions from bovine ruminal contents. J. Anim. Sci. 72, 2962-2968

National Research Council, 1985. Ruminant Nitrogen Usage. Natl. Acad. Sci., Washington, DC

Nocek J.E., Braund D.G., 1985. Effect of feeding frequency on diurnal dry matter and water consumption, liquid dilution rate, and milk yield in tirst lactation. J. Dairy Sci. 68, 2238-2247

Nocek J.E., Russell J.B., 1988. Protein and energy as an integrated system. Relationship of ruminal protein and carbohydrate availability to microbial synthesis and milk production. J. Dairy Sci. 71, 2070-2107

$\emptyset$ rskov E.R., McDonald I., 1979. The estimation of protein degradability in the rumen from incubation measurements weighted according to rate of passage. J. Agric. Sci., Camb. 92, 499-504

Robinson P.H., McNiven M.A., 1994. Influence of flame roasting and feeding frequency of barlcy on performance of dairy cows. J. Dairy Sci. 77, 3631-3643

Robinson P.H., McQueen R.E., 1994. Inlluence of supplemental protein source and feeding frequency on rumen fermentation and performance in dairy cows. J. Dairy Sci. 77, 1340-1353

Robinson P.H., Sniffen C.J., 1985. Forestomach and whole tract digestibility for actating dairy cows as influenced by feeding frequency. J. Dairy Sci. $68,857-867$

Roseler D.K., Ferguson J.D., Sniffen C. J., Herrema J., 1993. Dictary protcin degradability effects on plasma and milk urea nitrogen and milk nonprotein nitrogen in Holstein cows. J. Dairy Sci. 76, $525-534$ 
SAS ${ }^{6}$ Uscr's Guide, 1985. Statistics. Version 5 Edition. SAS Inst., Inc., Cary, NC.

Shabi Z., Arieli A., Bruckental I., Aharoni Y., Zamwel S., Tagari H., 1997. Effects of extrusion of corn grain and feeding frequency on rumen fermentation, nutrient digestibilities and milk yield and composition in dairy cows. 3. Dairy Sci. 80, Suppl. I, 212, P274

Shabi Z., Aricli A., Brukental I., Aharoni Y., Zamwel S., Bor A., Tagari H., 1998. Effect of the synchronization of degradation dictary crude protcin and organic matter degradation and feeding frequency on ruminal fermentation and abomasal digesta flow in dairy cows. J. Dairy Sci. 81 (in press)

Sutton J.D., Hart I.C., Broster W.H., Rosemary J.F., Schuller E., 1986. Feeding frequency for lactating cows: effects on rumen fermentation and blood metabolites and hormons. Brit. J. Nutr. $56,181-192$

Sutton J.D., Hart I.C., Morant S.V., Schuller E., Simmonds A.D., 1988. Feeding frequency for lactating cows: diurnal patterns of hormones and metabolites in peripheral blood in relation to milk-fat concentration. Brit. J. Nutr. 60, 265-274

Tagari H., 1969. Comparison of the efficiency of protein contained in lucerne hay and soya-bean meal for sheep. Brit. J. Nutr. 23, 455-470

Tamminga S., 1992. Nutrition management of dairy cows as a contribution to pollution control. $\mathbf{J}$. Dairy Sci. $75,345-357$

Van Soest P.J., Robertson J.B., Lewis B.A., 1991. Methods for dietary fiber, neutral detergent fiber, and non starch polysaccharides in relation to animal nutrition. J. Dairy Sci. 74, 3583-3597

Whitelaw F.G., Eadie J.M., Brucc L.A., Shand W.D., 1984. Methane formation in faunated and ciliate-free cattle and its relationship with rumen volatile fatty acid. Brit. J. Nutr. 52, 261-275

Yang C.M., Varga G.A., 1989. Effect of three concentrate feeding frequencies on rumen protozoa, rumen digesta kinetics, and milk yield in dairy cows. J. Dairy Sci. 72, 950-957

\section{STRESZCZENIE}

\section{Wpływ liczby odpasów na wydajność i skład mleka krów}

Doświadczenie przeprowadzono w przemysłowej fermic bydła na 180 krowach rasy holsztyńskiej (Israel Holstein), podzielonych na 2 grupy. W gnupie pierwszej paszę podawano raz dziennie, w drugiej - træy razy dziennie. Suma LKT i molarny udział kwasu octowego były wyższe przed karmieniem niż w 3 godz. po podaniu paszy. Obniżenie udziału kwasu octowego po odpasie było wiçkszc u krów otrzymujących paszę raz niż trzy razy dzienne. Udział kwasu propionowego był większy przed karmicnien i niższy w 3 godz. po odpasie u krów, kiórym paszę podawano 3 razy dziennie, w następstwie czego stosunek kwasu octowego do propionowego u krów żywionych 3 razy dziennie był niższy przed karmieniem i wzrastał po 3 godzinach. Stężenic $\mathrm{NH}_{3} \mathrm{~N}$ w żwaczu, przed i po karmieniu, bylo niższe u krów otrıymujących paszę 3 razy dziennie. Zawartość N-mocznikowego w osoczu krwi była wyższa przed odpasem niż 3 godz. później i była wyærša u krów żywionych jednorazowo, ale istotną różnicę stwicrdzono tylko w 3 godz. po rannym karmieniu. Można sądzić, że zwiększenie częstotliwości podawania paszy możc poprawiać wykorzystanie azotu pasıy i mołe wpływać na zmianę kierunku przemian, zwiększając glukoncogenezc.

Zmiany w wydajności w zależności od częstotliwości podawania paszy mogą się ujawnić u krów wysokowydajnych, żywionych dawkami z dużym udziałem paszy treściwej. 